\title{
Bahiagrass (Paspalum notatum Flueggé): Overview and Pasture Management ${ }^{1}$
}

\author{
Marcelo Wallau, Joao Vendramini, José Dubeux, and Ann Blount ${ }^{2}$
}

Bahiagrass (Paspalum notatum Flueggé) is the most common and widely used warm-season perennial grass in Florida. Originally from South America, it is planted on over two million acres in the state and on over four million acres in the southeastern United States. The adaptation to low soil fertility and low input management makes the species one of the most popular for livestock production in Florida. It can be established by seed and is used mainly for pasture and hay production with adequate yield and acceptable animal performance. It is well adapted to the southern Coastal Plain region of the US. It establishes well in sandy soils with limited water retention and low inherent soil fertility, and is tolerant to drought, sporadic flooding, and continuous stocking.

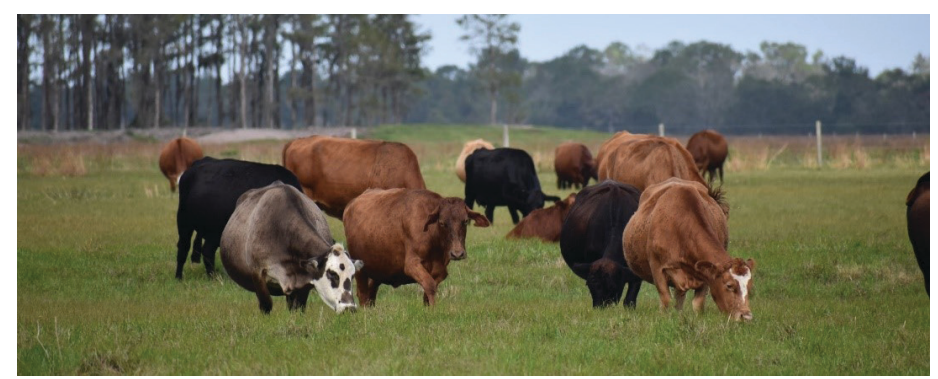

Figure 1. Bahiagrass pasture in central Florida.

Credits: Marcelo Wallau, UF/IFAS
Bahiagrass is a dense, prostrate grass with leaves that are crowded at the base with shallow but sturdy underground stems (rhizomes). It can grow 12-25 inches tall, and the seedhead is typically a two-branched raceme with protruding anthers for pollen production with characteristic purple coloration (Figure 2). The main mode of reproduction is by seed, but bahiagrass also spreads vegetatively by rhizomes. It is best adapted to sandy loam soils and tolerates low fertility. It grows on soils with an acidic $\mathrm{pH}$ from 4.5 to 6.5, but the optimal (target) soil $\mathrm{pH}$ is 5.5. At $\mathrm{pH}$ greater than 6.5 , the grass is often yellow and stunted. Bahiagrass grows vigorously under high temperature and long days, although there are differences between cultivars in day-length sensitivity. Approximately $85 \%$ of the production occurs during the six warmest months (April through September).

\section{Forage Cultivars}

The center of origin of this grass is subtropical South America. It is abundant in northern Argentina, Brazil, eastern Bolivia, and Paraguay. In Florida, bahiagrass has a century-long history as "common" bahiagrass. It was first introduced by the Bureau of Plant Industry and grown by the Florida Agricultural Experiment Station in 1913.

1. This document is SS-AGR-332, one of a series of the Agronomy Department, UF/IFAS Extension. Original publication date May 2010. Revised July 2019. Visit the EDIS website at https://edis.ifas.ufl.edu for the currently supported version of this publication.

2. Marcelo Wallau, assistant professor, forage Extension specialist, Agronomy Department; Joao Vendramini, professor, Agronomy Department, UF/IFAS Range Cattle Research and Education Center; José Dubeux, associate professor, Agronomy Department, UF/IFAS North Florida Research and Education Center; and Ann Blount, professor, forage breeding and management Extension specialist, Agronomy Department, UF/IFAS NFREC; UF/IFAS Extension, Gainesville, FL 32611.

The use of trade names in this publication is solely for the purpose of providing specific information. UF/IFAS does not guarantee or warranty the products named, and references to them in this publication do not signify our approval to the exclusion of other products of suitable composition. All chemicals should be used in accordance with directions on the manufacturer's label. Use pesticides safely. Read and follow directions on the manufacturer's label.

The Institute of Food and Agricultural Sciences (IFAS) is an Equal Opportunity Institution authorized to provide research, educational information and other services

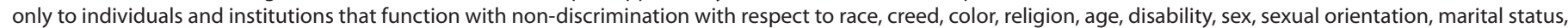

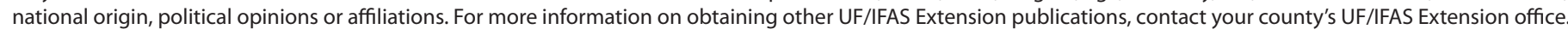
U.S. Department of Agriculture, UF/IFAS Extension Service, University of Florida, IFAS, Florida A \& M University Cooperative Extension Program, and Boards of County Commissioners Cooperating. Nick T. Place, dean for UF/IFAS Extension. 


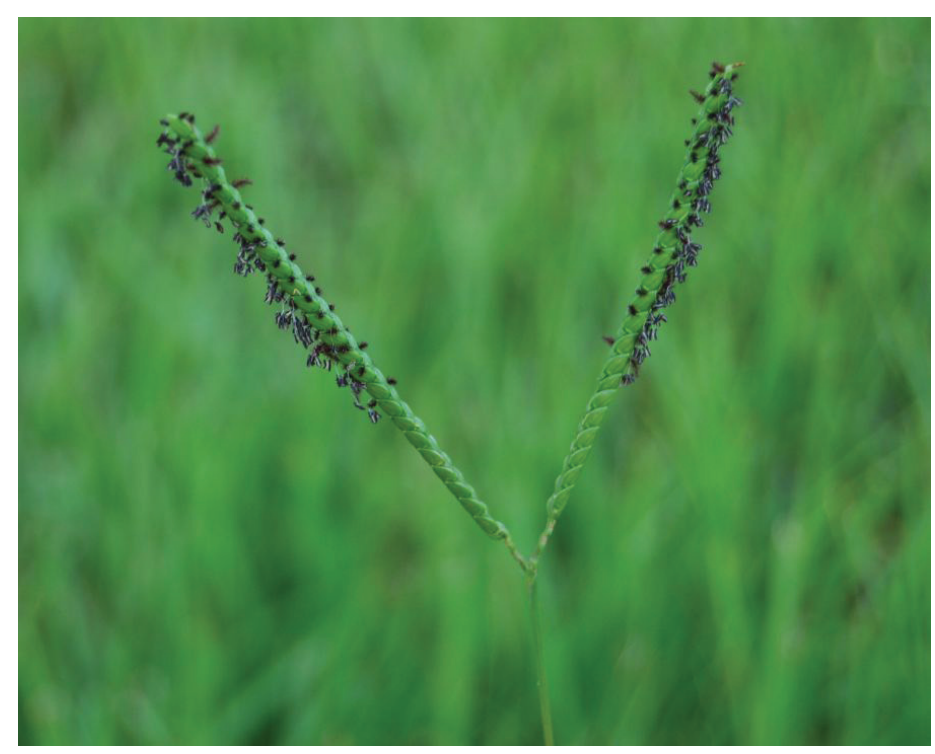

Figure 2. Bahiagrass seedhead. The purple anthers can be observed covering each raceme.

Credits: Carlos Acuna, UF/IFAS

There are several cultivars of bahiagrass available, and the best choice varies depending on the intended use and location. Genetically, there are two types or ploidy levels (i.e., number of sets of chromosomes) in bahiagrass: diploids and tetraploids. Diploids are more adapted to the northern part of the state and include Pensacola, Tifton 9, TifQuik, and UF-Riata. The tetraploid cultivars are more favored in south Florida and include Argentine, Paraguay, Paraguay 22, and "common bahiagrass." Argentine bahiagrass has become popular in northern Florida for wetter pasture sites that are often overseeded with cool-season forages as the summer grass becomes dormant.

Pensacola-This cultivar is thought to originate from the Santa Fe Province of Argentina and is believed to have arrived in the Pensacola area of Florida probably as ship ballast or bedding in the 1920s. Pensacola was identified in 1938 by E. H. Finlayson, an Escambia County Extension agent. He collected and distributed seed of this bahiagrass and promoted it for pastures and land conservation.

Pensacola bahiagrass is a diploid type with narrow leaves and good seed production, and it is very persistent under intensive grazing. It is more cold-tolerant than most tetraploid types. Production concentrates from early spring to mid-summer and slows towards the end of the summer and fall. Most bahiagrass pastures in the southeastern United States today are planted to Pensacola, and 60\% of the bahiagrass acreage in Florida is estimated to be Pensacola.

Tifton 9-Tifton 9 is a selection from Pensacola that was found to have superior yields in early spring and late fall and greater seedling vigor. It has a more upright growth habit and does not form as thick a sod as Pensacola but yields around 10 to $30 \%$ more dry matter. Tifton 9 is estimated to occupy $10 \%$ of the bahiagrass acreage in Florida. This cultivar was developed by Dr. Glenn Burton and released by the University of Georgia and the US Department of Agriculture (USDA) in 1989.

TifQuik - TifQuik is a cultivar that was developed from Tifton 9 through restricted, recurrent selection for fewer hard seeds (seeds that are alive but will not germinate immediately upon planting), superior seedling vigor, and quicker stand formation. Spring growth occurs earlier than Tifton 9 or Pensacola. Yield potential and other characteristics are similar to those of Tifton 9. TifQuik was released by the USDA and the University of Georgia.

UF-Riata-UF-Riata was selected from the Pensacola cultivar for low sensitivity to day length, providing further improvement in early spring and late fall production. Peak production in the summer is not as consistent as that of other cultivars; nevertheless, it has the longest growing season among available cultivars. In central and south Florida, it is common to see UF-Riata green and productive well into the winter or until the first frost. It may be an alternative for extending the grazing season. The University of Florida released this cultivar in 2007.

Common-This bahiagrass has prostrate growth habit, with short, broad leaves and thick rhizomes. It is coldsensitive, but its rhizomatous growth habit makes it persistent under grazing. It is still common and popular in south Florida, growing in old, established pastures.

Paraguay and Paraguay 22-These ecotypes were plant introductions from Paraguay; they are more upright than common bahiagrass but are not routinely used in pastures. They are less productive and cold-tolerant than Pensacola and have short, coarse, and narrow leaves. Paraguay 22 was popularized because it was thought to be ergot-resistant. Very few acres planted to Paraguay 22 remain in Florida.

Argentine-This ecotype was introduced from Argentina in 1944. It is highly productive with excellent spreading but lower seed production compared to Pensacola. Argentine is less cold-tolerant than Pensacola and is susceptible to ergot. It starts producing forage later in spring, concentrating production during the summer months, but it has a similar total tonnage to that of Pensacola. It is estimated that Argentine makes up 25\% of total bahiagrass acreage in Florida, but mainly in south Florida. 
Wilmington-Wilmington is better adapted to northern regions of the state. It is a cold-tolerant, tetraploid bahiagrass. Despite its ploidy level, it has narrow leaves that are dark green in color. Wilmington was originally collected in coastal North Carolina. It is not as productive as other bahiagrass types, but it may have turf potential.

\section{Forage Production}

Bahiagrass forage production is variable depending on cultivar, management, environment, and site characteristics. Annual forage production typically ranges from 3,000 to $10,000 \mathrm{lb}$ dry matter (DM)/acre (Table 1 ), or even up to $14,000 \mathrm{lb} \mathrm{DM} /$ acre under high fertilization. Bahiagrass is normally more productive under the combination of high temperature, moisture, and long days (Figure 3). Selected cultivars such as Tifton 9 and UF-Riata are generally more productive (Vendramini et al. 2013). Diploid cultivars (i.e., Pensacola types) tend to be less sensitive to photoperiod and start producing earlier in the spring compared to tetraploids (e.g., Argentine). Low rainfall during March, April, and May will limit forage production, especially on well-drained sandy soils. In south Florida, under warm conditions and mild winters, production is usually above that reported in central and north Florida by $30 \%$ or more. Fall production is limited by rainfall and short days, when the plants start accumulating reserves for winter dormancy.

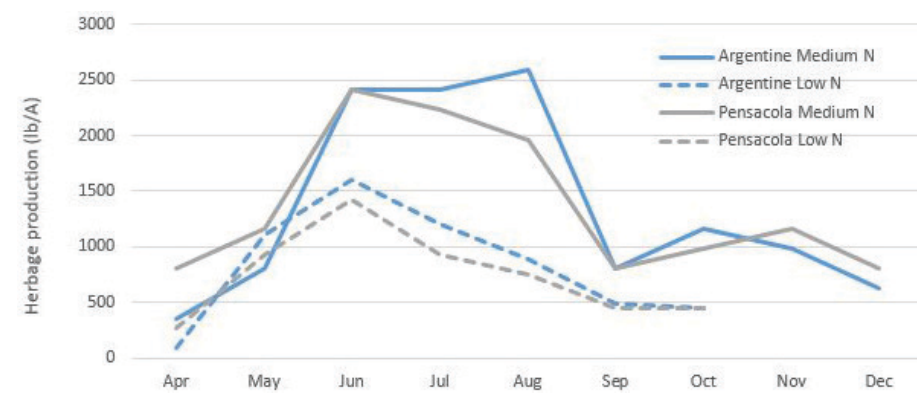

Figure 3. Herbage production for Argentine (blue lines) and Pensacola (gray lines) bahiagrass under medium (100 lb N/A; solid lines) (Mislevy et al. 2003) and low (53 lb N/A; dashed lines) (Vendramini et al. 2013) nitrogen fertilization.

Credits: UF/IFAS

Grazing management also influences forage productivity. A 4 -week resting interval produced almost $50 \%$ more forage compared to 2 weeks in south Florida for several different cultivars when grazed to a 3 -in stubble height (Vendramini et al. 2013). Furthermore, the less intensive grazing also resulted in greater root and rhizome mass, providing an advantage under drought. Rotational stocking will result in greater productivity than continuous stocking and has been shown to provide approximately 60 (ranging from 40 to 100 $\mathrm{lb} / \mathrm{acre}$ per day) vs. $40 \mathrm{lb} / \mathrm{acre}$ of dry matter per day (Stewart et al. 2005). Despite the high resistance of bahiagrass to heavy grazing, high intensity (stubble shorter than 3 in) or frequency (e.g., 2- vs. 4-week intervals) can result in reduction in cover, especially for upright growing cultivars such as UF-Riata and Tifton 9. Argentine bahiagrass normally has greater cover than other cultivars, even under frequent grazing (Interrante et al. 2009; Vendramini et al. 2013).

\section{Nutritive Value}

Nutritive value is a function of month, fertilization, and grazing management. Energy concentration of bahiagrass, which is reflected in digestibility of the forage, declines considerably as the season progresses, regardless of fertility or defoliation management. In vitro digestibility drops to below $50 \%$ by 5 weeks of regrowth (Figure 4) (Carvalho 1976), but when grazed every 2 to 4 weeks, it maintains levels between $60 \%$ (early season) and 50\% (summer) (Vendramini et al. 2013). Different studies show that wellfertilized bahiagrass contains about $10-15 \%$ crude protein (CP), but values for most unfertilized pastures will be lower (Figure 5) (Stewart et al. 2005). Crude protein decreases as the season progresses (15\% in the spring vs. $10 \%$ in the summer) but is markedly affected by grazing frequency. Pastures grazed every 7 days had 14\% CP, dropping to $12 \%$ for a 21-day interval (Interrante et al. 2009). Concentrations of phosphorus $(\mathrm{P})$ in leaf tissue may range from 0.15 to $0.4 \%$, and concentrations of potassium $(\mathrm{K})$ may range from 1.2 to $2.5 \%$. If the leaf concentrations of phosphorus drop below $0.15 \%$, or $1.2 \%$ for potassium, the addition of fertilizer will be necessary to maintain adequate forage production.

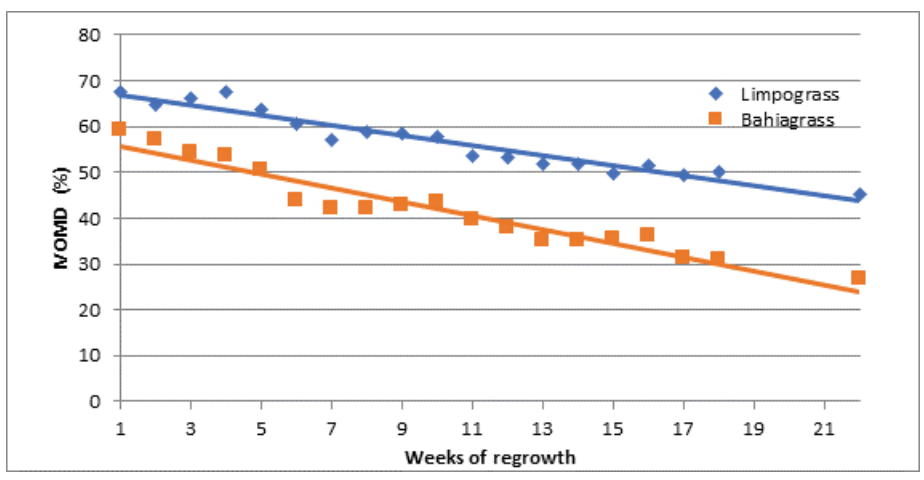

Figure 4. Decline in Pensacola bahiagrass and Floralta limpograss in vitro organic matter digestibility (IVOMD) by weeks of regrowth. Adapted from Carvalho (1976).

Credits: Carvalho (1976) 


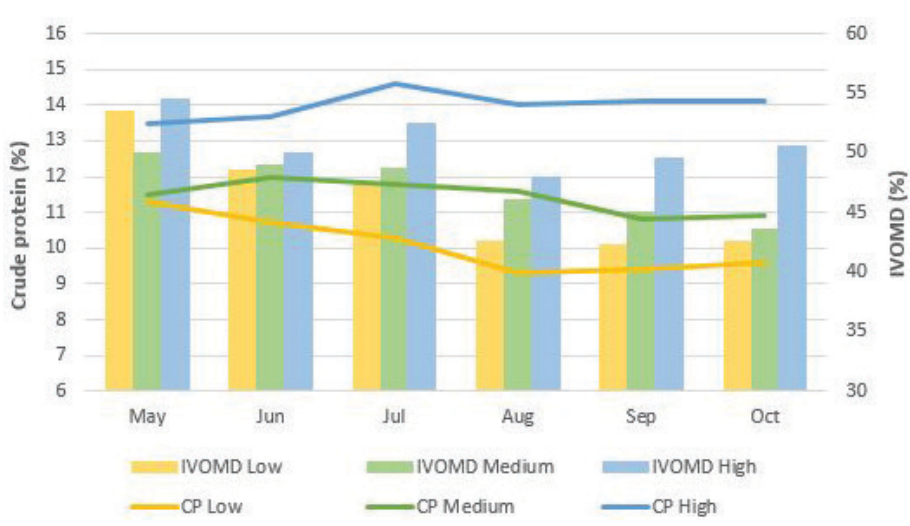

Figure 5. Crude protein (lines; \%) and in vitro organic matter digestibility (bars; \%) of Pensacola bahiagrass under three management levels: low (40 lb N/acre.year), medium (120 lb N/acre. year), and high (360 lb N/acre.year) fertilization level.

Credits: Stewart et al. (2007)

\section{Animal Performance}

Because of the medium to low nutritive value, bahiagrass alone is not well suited for livestock with high nutritional requirements, such as growing or lactating animals. Average daily gains (ADG; lb of live weight gain/day) of cattle on bahiagrass are usually lower (around $1 \mathrm{lb} /$ day) than other warm-season perennial grasses such as limpograss or bermudagrass (up to $2 \mathrm{lb}$ /day in some cases). Studies on continuously stocked bahiagrass pastures have ADG of crossbred yearling heifers ranging from 0.3 to $1.2 \mathrm{lb} /$ day. However, these numbers generally decline from summer to fall: ADG will often range from 1.2 to $1.3 \mathrm{lb} /$ day in June-July to 0.3 to $0.4 \mathrm{lb}$ /day in August-September and are typically lower $(0.2 \mathrm{lb} /$ day $)$ after September. When pastures are understocked in the summer, daily gains are usually low due to a reduction in forage nutritive value. However, high grazing intensity associated with short canopy height limits the animal's grazing capacity; despite the greater nutritive value of pastures with high stocking rate, animal gains are lower (0.62 vs. $0.75 \mathrm{lb}$ gain/day; Table 2) (Stewart et al. 2007).

\section{Planting}

Bahiagrass is mostly established by seed. However, sod may be used for faster establishment of bahiagrass meant for landscaping. Before establishing any pasture, choose a site to which it is adapted, soil test and amend if necessary, control weeds, and prepare the seedbed properly. For more detailed guidelines for land preparation, see EDIS document SS-AGR-161, Forage Planting and Establishment Methods on Prepared Seedbed (http://edis.ifas.ufl.edu/ ag107). It is important to prepare the area beforehand to ensure good establishment, especially when liming and weed control are required. Planting on a clean seedbed is essential for good establishment: weed control is easier and cheaper if done prior to establishing bahiagrass. From emergence to approximately 6 inches in height (seedling stage), bahiagrass does not tolerate most herbicides.

In Florida, it is best to establish bahiagrass during the rainy season (June-August). However, if irrigation is available, bahiagrass can be planted as early as March and possibly earlier in south Florida. Better results are obtained if planting in March, since bahiagrass will come up before summer annual weeds. When planting without irrigation, late March through early May in south Florida or mid-April to June in north Florida should be avoided because those months are more prone to drought periods.

After the seedbed is prepared and before broadcasting the seed, pack the soil with a roller to firm the seedbed and drill the seeds $1 / 4$ to $1 / 2$ inch deep. Using a cultipacker planter or any seed drill helps to place the seeds at a uniform and adequate depth. If a drill is not available, seeds can be broadcasted and rolled afterwards. Disking seeds can be risky because it is easy to bury the seed too deep. Seeding rates range from 20 to $30 \mathrm{lb} /$ acre, depending on the cultivar. TifQuik and UF-Riata have fewer hard seeds and a quicker establishment, but the more upright growth habit can result in longer time to form a closed stand if the seeding rate is low. Low seeding rates can result in bare spots (especially with UF-Riata and TifQuik) and will encourage weed encroachment. High seeding rates (up to $50 \mathrm{lb} / \mathrm{acre}$ ) will speed up establishment and increase the biomass production in the first two years; however, differences in production and cover tend to disappear after the third year.

Light fertilization of bahiagrass will generally be necessary within 7-10 days after seedling emergence. The initial application should consist of $30 \mathrm{lb}$ nitrogen $(\mathrm{N}) /$ acre, all of the recommended $\mathrm{P}_{2} \mathrm{O}_{5}$, and $50 \%$ of the recommended $\mathrm{K}_{2} \mathrm{O}$. Approximately 40-50 days after the initial application, an additional $50 \mathrm{lb}$ of nitrogen and the remaining $\mathrm{K}_{2} \mathrm{O}$ should be applied. If manure or biosolids are used as the main source of nutrients, apply the entire annual application at one time after the plants are large enough to withstand physical damage from the application. Well-fertilized plants will form a dense stand in 60-90 days, and light grazing or mowing can be done.

\section{Pasture Renovation}

The strategy for renovation will depend on the conditions of the pasture. In most cases, the best strategy is to provide optimal recovery conditions by reducing grazing pressure and applying fertilizer and necessary herbicides for weed control. Most bahiagrass pastures will not benefit from 
additional seed or tillage. Only in cases of very open stands will this be useful (Gates 2000). If stands are excessively compromised, it is probably best to start over (complete renovation) with recommended practices mentioned in the previous section. In complete renovation, it is recommended to start preparing the area in advance (in the fall) with a good kill of current stand and weeds, followed by planting a cool-season annual forage for winter grazing, and to then seed bahiagrass the following spring. If a new cultivar will be used, then skipping one summer season (e.g., planting a summer annual) will help reduce the soil seed bank. Practices such as aerating have minimal effect on pasture productivity or recovery (see EDIS document SS-AGR-321, Pasture Aeration, https://edis.ifas.ufl.edu/ ag331). A quick flush of nutrients released from organic matter mineralization may result in a fast green up, but the benefits are temporary and are not expected to improve forage production in the medium or long term (Kalmbacher and Williams 1993).

\section{Management}

\section{Fertilizer and Liming Recommendations}

Soil testing should precede any fertilization practice. Fertilization for bahiagrass varies depending on the type and intensity of use. The target soil $\mathrm{pH}$ is 5.5. If liming is necessary, it is recommended to lime three to six months prior to fertilization to allow the lime to react with the soil. Test your soil pH every two to three years. For more detailed information on fertilization, please refer to EDIS document SL129, UF/IFAS Standardized Fertilization Recommendations for Agronomic Crops (http://edis.ifas.ufl. edu/ss163).

\section{Fertilization for Grazed Pastures PHOSPHORUS FERTILIZATION}

Special attention should be given to phosphorus fertilization in order to avoid environmental problems associated with nutrient losses in the sandy soils of Florida. A soil test alone is not adequate to determine bahiagrass phosphorus needs. Producers are encouraged to submit both a soil test and a tissue sample. For information on how to submit a tissue sample, see EDIS document SL252, Tissue Analysis as a Nutrient Management Tool for Bahiagrass Pastures (http:// edis.ifas.ufl.edu/ss475). For additional information, see EDIS document SL249, Getting the Most out of Bahiagrass Fertilization (http://edis.ifas.ufl.edu/ss469).

\section{ESTABLISHED PASTURES}

Nitrogen is the nutrient that is most limiting to bahiagrass growth, so producers should first consider needs and the amount of nitrogen they can afford. A medium nitrogen option for grazed, established stands is to apply $100 \mathrm{lb} \mathrm{N} /$ acre. The application should be evenly split; the first $50 \mathrm{lb}$ $\mathrm{N} /$ acre and all of the soil test-recommended $\mathrm{P}_{2} \mathrm{O}_{5}$ and $\mathrm{K}_{2} \mathrm{O}$ levels should be applied in early spring. The second $50 \mathrm{lb}$ $\mathrm{N} /$ acre should be applied in early summer. For a minimum fertilization alternative, apply 50-60 lb N/acre in the early spring to provide much-needed forage. Do not apply $\mathrm{K}$ since $\mathrm{N}$ will be the limiting nutrient that the bahiagrass is dependent upon in this low-cost option. Apply $25 \mathrm{lb}_{2} \mathrm{O}_{5} /$ acre if your soil tests "Low" in $\mathrm{P}$ and tissue $\mathrm{P}$ concentration is below $0.15 \%$. Do not apply $\mathrm{P}$ if tissue $\mathrm{P}$ concentration is at or above $0.15 \%$, even if the soil tests "Low" in P. For "Medium" and "High" soil P levels, neither P application nor tissue analysis is recommended since there will be no added benefit of $\mathrm{P}$ fertilization on bahiagrass yields.

Many producers opt for a "minimum fertilization" strategy, withdrawing any $\mathrm{P}$ and $\mathrm{K}$. This, however, can have negative long-term consequences. A recent study in response to producer concerns investigated the decline in stands of bahiagrass pastures throughout the state. Most pastures were over 10 years old, received minimal fertilization, and had $\mathrm{pH}$ below target for bahiagrass (5.5). Potassium fertilization increased forage accumulation and cover in most sites, while liming improved forage production in half of the sites (Sollenberger 2019). Thus, even for established bahiagrass pastures, it is important to soil test frequently (every 3 years) and replenish $\mathrm{P}$ and $\mathrm{K}$ levels when needed.

\section{FERTILIZATION FOR HAY PRODUCTION ONLY}

Apply $80 \mathrm{lb}$ N/acre in early spring along with $80 \mathrm{lb} \mathrm{K}_{2} \mathrm{O}$ / acre if your soil tests "Very Low" or "Low" in K and $40 \mathrm{lb}$ $\mathrm{K}_{2} \mathrm{O}$ /acre if it tests "Medium." Apply $40 \mathrm{lb}_{2} \mathrm{O}_{5}$ /acre if your soil tests "Low" in $\mathrm{P}$ and tissue $\mathrm{P}$ concentration is below $0.15 \%$. Apply an additional $80 \mathrm{lb} \mathrm{N} /$ acre and $40 \mathrm{lb} \mathrm{K}_{2} \mathrm{O} /$ acre after each cutting, except the last in the fall. Include $20 \mathrm{lb}$ $\mathrm{P}_{2} \mathrm{O}_{5}$ /acre after each cutting if the soil tested "Low" in P.

\section{FERTILIZATION FOR SEED PRODUCTION}

Apply 60-80 lb N/acre in February or March (south Florida) or April (north Florida), plus $80 \mathrm{lb} \mathrm{K}_{2} \mathrm{O} /$ acre if your soil tests "Low" in $\mathrm{K}$, or $40 \mathrm{lb} \mathrm{K}_{2} \mathrm{O}$ /acre if it tests "Medium", and $40 \mathrm{lb}_{2} \mathrm{O}_{5}$ /acre if your soil tests "Low" in $\mathrm{P}$ and tissue $\mathrm{P}$ concentration is below $0.15 \%$. Graze until May, June, or July, depending on the variety. Remove cattle before seedheads start to emerge and apply an additional 60-80 lb N/acre. 
If the bahiagrass is not grazed, do not apply fertilizer in February or March since this may stimulate excessive top growth. Mowing or burning from February to April may be needed to remove excessive top growth. These practices can increase seed production and reduce foliar diseases. Apply 60-80 lb N/acre before seedheads first appear. Apply $25 \mathrm{lb} \mathrm{P}_{2} \mathrm{O}_{5}$ /acre if your soil tests "Low" in $\mathrm{P}$ and tissue $\mathrm{P}$ concentration is below $0.15 \%$. Do not apply $\mathrm{P}$ if tissue $\mathrm{P}$ concentration is at or above $0.15 \%$, even if the soil tests "Low" in P. For "Medium" and "High" soil P levels, neither $\mathrm{P}$ application nor tissue analysis is recommended. Apply 50 $\mathrm{lb} \mathrm{K}_{2} \mathrm{O} / \mathrm{acre}$ if your soil tests "Low" in $\mathrm{K}$ and none if it tests "Medium" or "High." Fertilize Pensacola, Tifton 9, TifQuik, and UF-Riata in March/April and Argentine in May/June.

\section{Weed Control}

Bahiagrass seedlings are susceptible to phenoxy-type herbicides (2,4-D, dicamba, others). These should not be applied until seedlings are at least 6 inches tall. Diploid bahiagrass cultivars (Pensacola, Tifton 9, UF-Riata, and TifQuik) will be severely injured by metsulfuron. When diploid types of bahiagrass are weeds in a bermudagrass pasture, metsulfuron will selectively and effectively remove the bahiagrass without harming bermudagrass. Tetraploid Argentine bahiagrass is more difficult to control and eliminate with selective grass herbicides because of its higher ploidy level.

Bahiagrass pastures that are well fertilized and growing under optimal conditions will be competitive with weeds. However, many ranchers in Florida use low fertility management, which may require additional intervention for weed control. Most broadleaf weeds can be controlled with dicamba (Banvel, Clarity, or Vanquish), 2,4-D (several brands), aminopyralid, or a combination of these. Sulfosulfuron (Outrider) can be applied to established pastures for control of annual or perennial sedges. Hexazinone (Velpar) is used for smutgrass control, but sprays of this herbicide must be kept away from desirable trees, especially oaks. To control specific weeds, there are many options. For more information, see EDIS document SS-AGR-08, Weed Management in Pastures and Rangeland (http://edis.ifas.ufl. edu/wg006).

\section{Grazing Management}

Bahiagrass is a highly persistent grass that has high tiller, rhizome, and root density. Because of its rhizomes and low growing points, bahiagrass is able to withstand close defoliation. The stubble height in midsummer should be approximately 2 inches for hay production, 3 inches for rotational grazing, and 5 inches if under continuous stocking. There is plenty of evidence that bahiagrass will become weak and stand loss will eventually occur when pastures are overgrazed. On the other hand, rapid growth of bahiagrass is associated with rapid decline in nutritive value. By increasing the stocking during rapid growth of bahiagrass, excess old growth can be avoided. A strategy to increase grazing pressure during the peak of productivity (summer) without increasing stock numbers in the ranch is to fence off part of the pasture to use for cutting hay or as stockpiled forage for later grazing, although nutritive value will be very low.

\section{Association with Other Forage Species}

The use of other forage species in association with bahiagrass can help extend the grazing season and/or increase forage nutritive value. In late fall, bahiagrass can be overseeded with annual ryegrass, small grains, or clovers. In north Florida and on soils of central Florida that hold soil moisture, annual ryegrass, small grains, clovers including crimson, white, ball, berseem, and red clover, and medics are recommended. Berseem and white clover can be planted in central and south-central Florida. Because of the dense nature of bahiagrass sod, competition from bahiagrass needs to be suppressed or minimized before overseeding with the legumes. A common practice is to graze it very short (height range) as the fall season approaches and afterwards do a light disking of the soil to suppress bahiagrass competition when establishing legume seedlings. Burning after the first frost or after applying a low rate of glyphosate (up to $16 \mathrm{oz} /$ acre) can suppress bahiagrass growth and reduce competition when drilling cool-season forages. Management during the transition in the spring is also very important. Late-growing species such as ryegrass can delay the onset of bahiagrass growth in the following season. Close grazing or mowing can be used to reduce competition during the spring transition period.

During the summer, companion legumes to bahiagrass are aeschynomene and carpon desmodium in moist, flatwood soils; or alyceclover, cowpeas, hairy indigo, stylo, and perennial peanut in well-drained areas. Strip-planting rhizoma peanut is a viable alternative to increase the nutritive value of the pasture, reduce the need for nitrogen fertilizer, and increase animal performance. For more information on establishing rhizoma peanut into existing bahiagrass pastures, see EDIS document SS-AGR-421, Strip-Planting Rhizoma Peanut into Grazing Systems (http:// edis.ifas.ufl.edu/ag421). 


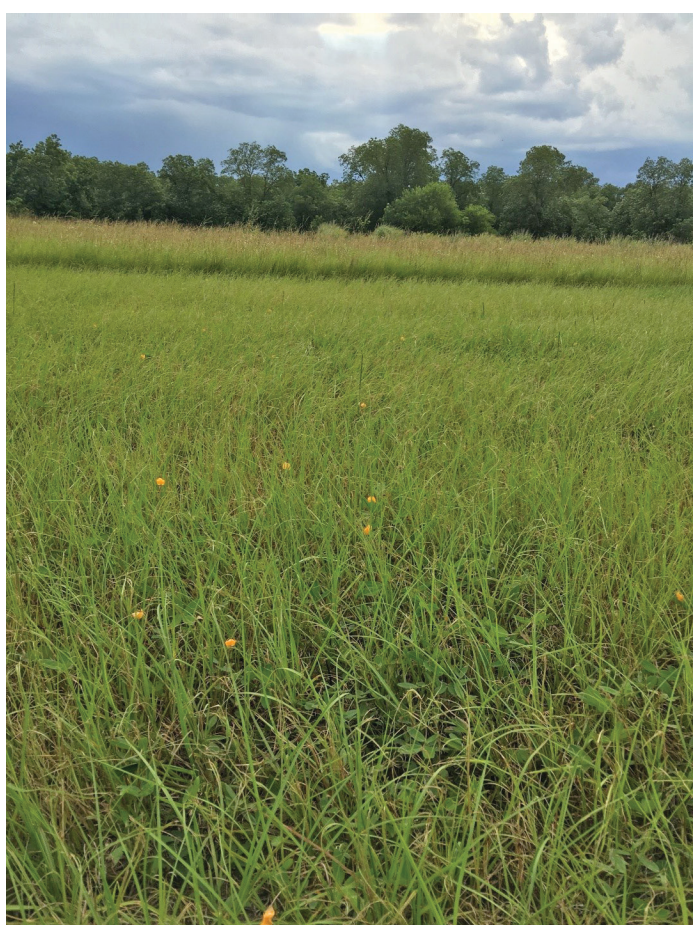

Figure 6. Bahiagrass and perennial peanut association. Credits: José Dubeux, UF/IFAS

\section{Other Utilization}

\section{Hay}

Well-fertilized bahiagrass cut at an immature growth stage will make decent hay. The quality of the grass drops dramatically as forage matures, especially if seedheads are present. Tifton 9, TifQuik, and UF-Riata have a more upright growth and are recommended for producers who want to grow bahiagrass exclusively as a hay crop. The challenge of bahiagrass hay production is that the peak of production is during the summer, when chances of precipitation are high. Alternatively, hay bales can be wrapped (haylage or silage), but this practice is normally done with higher-quality hay such as hybrid bermudagrass.

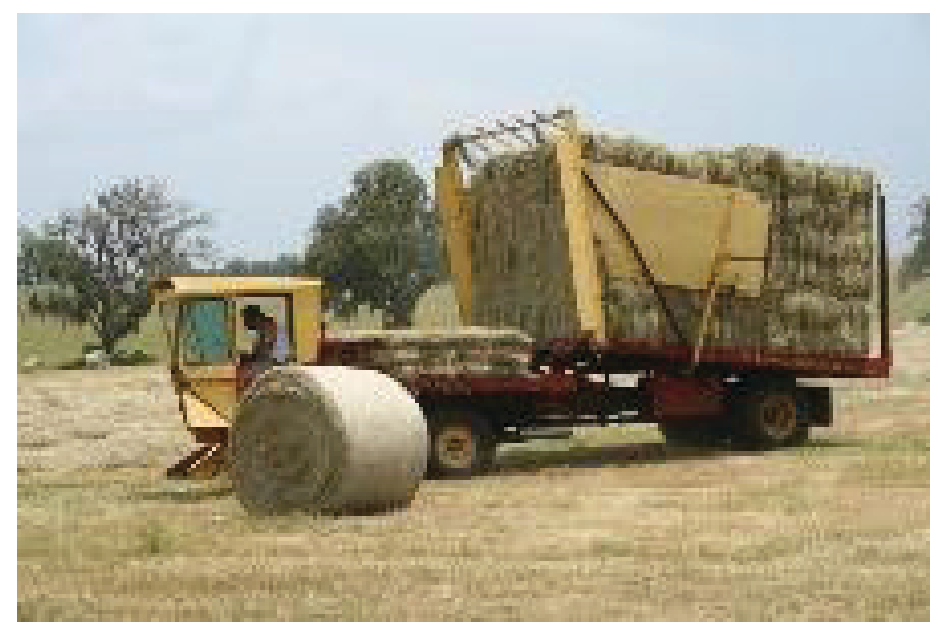

Figure 7. Round bales and square bales of bahiagrass hay.

Credits: Yoana Newman, UF/IFAS

\section{Seed Production}

Bahiagrass seed from Argentine, Paraguay 22, and Pensacola is produced regularly by some ranches to generate additional income. Frequently, seed companies harvest, process, and market the seed. Bahiagrass is an obligate, long-day plant that will produce the most inflorescences (seedheads) with long days. Argentine bahiagrass will flower only at day lengths greater than 13.8 hours in Florida.

Highest seed yields are obtained when forage residue from the previous growing season is removed between late April and May and immediately fertilized. If residue is removed early or high $\mathrm{N}$ fertilizer is applied, more vegetative growth will occur with fewer flowering stems. Usually, the management of pastures for seed production requires fertilization in early spring and grazing until the longest days approach or the first signs of flowering occur in early June.

It is not legal to harvest and sell seed of varieties that have plant variety protection (PVP), such as Tifton 9, TifQuik, or UF-Riata. These varieties are protected by federal seed laws and can only be sold by variety name. When purchasing seed of any variety of bahiagrass, it is best to buy from a reputable seed source. Labels on the seed bag should indicate the state variety, percentage seed germination, date of testing, and purity.

\section{Other Uses}

Bahiagrass has several other uses, including sod production, lawns, and crop rotation. For additional information on other uses, please refer to the EDIS documents below:

- SS-AGR-126, Sod/Livestock-Based Peanut/Cotton Production System: The Next Generation Conservation Cropping System (http://edis.ifas.ufl.edu/ag258)

- ENH6, Bahiagrass for Florida Lawns (http://edis.ifas.ufl. edu/lh006)

\section{Insects and Plant Diseases}

Mole crickets can cause serious damage to bahiagrass pastures in Florida. There are three pest species (Scapteriscus spp.) found in Florida: the southern, tawny, and short-winged mole cricket. Of these three, the tawny mole cricket is the most damaging. Insecticidal-nematode control (Steinernema scapterisci) and biological control with the Larra wasp (Larra bicolor) are efficient against mole crickets, but rarely available in the market.

Bahiagrass is susceptible to "dollar spot" (Sclerotinia homoeocarpa) and ergot (Claviceps paspali) diseases in 
hot, damp weather conditions (July-early September). These diseases will affect seed and production yield, but, in general, neither of these diseases is toxic or a problem to livestock. Ergot is a possible concern associated with reproductive and behavioral problems in livestock, including abortion in pregnant mares. If ergot is present, it can be managed by mowing the seedheads. Dollar spot seems to be more severe in Pensacola-type bahiagrass than in Argentine. Few fungicides are registered for use on forage crops used for grazing and hay or silage production, and even if labeled, application may not be economically viable. The label is the law and any use of a registered fungicide on a forage must adhere to the withdrawal restrictions, if applicable, for grazing, hay, or silage use. The best practice for fungal diseases in bahiagrass is to graze or cut to remove pathogens or eliminate thatch (especially burning) to reduce inoculum for the next growing season.

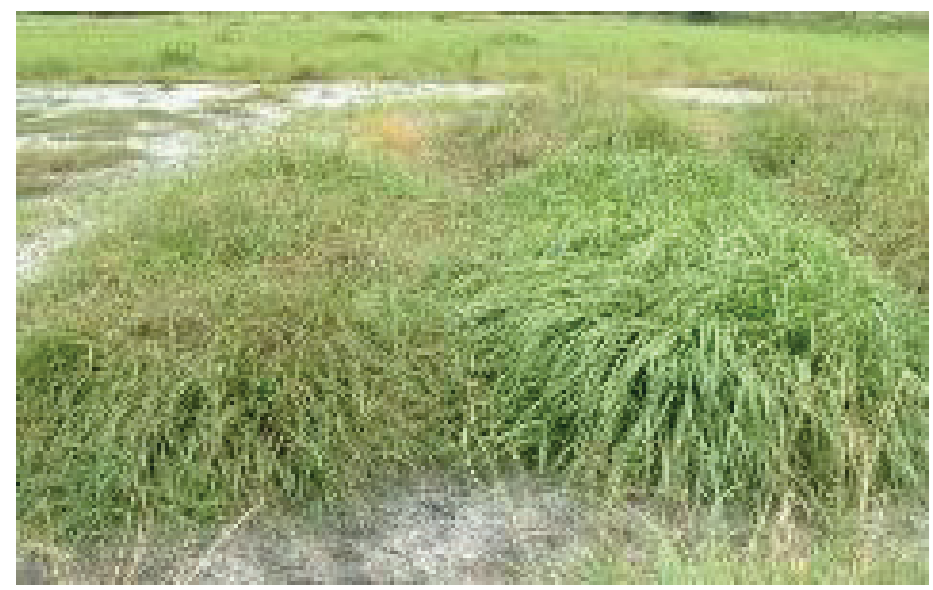

Figure 8. Dollar spot on Pensacola-type (left) and Argentine (right) bahiagrass cultivars.

Credits: Ann Blount, UF/IFAS

\section{Conclusion}

- Bahiagrass is a warm-season plant adapted to areas of low soil fertility typical of Florida's deep, sandy soils. It does not grow well in $\mathrm{pH} 6.5$ and higher, and $\mathrm{pH}$ below 5.5 can negatively affect yield and stand survival.

- Bahiagrass production is highest during midsummer when days are long.

- Bahiagrass has low to medium crude protein and digestibility.

- Pensacola and Argentine are recommended cultivars for grazing. Tifton 9 and UF-Riata are also recommended for hay production. UF-Riata is a good alternative to extend the production season in the fall.

\section{References}

Adjei, M. B., P. Mislevy, and W. Chason. 2000. “Timing, defoliation management, and nitrogen effects on seed yield of 'Argentine' bahiagrass.' Agron. J. 92: 36-41.

\section{Carvalho, J. H. 1976. Plant Age and Its Effect upon Forage}

Quality. Master's thesis. Gainesville: University of Florida Institute of Food and Agricultural Sciences.

Gates, A. R. N. 2000. "Response of incomplete Tifton 9 bahiagrass stands to renovation." J. Range Manag. 53(6): 614-616.

Interrante, S. M., L. E. Sollenberger, A. R. Blount, S. W. Coleman, U. R. White, and K. Liu. 2009. "Defoliation management of bahiagrass germplasm affects cover and persistence-related responses." Agron. J. 101(6): 1381-1387.

Inyang, U., J. M. B. Vendramini, L. E. Sollenberger, B. Sellers, A. Adesogan, L. Paiva, and A. Lunpha. 2010. "Forage species and stocking rate effects on animal performance and herbage responses of 'Mulato' and bahiagrass pastures." Crop Sci. 50: 1079-1085.

Kalmbacher, R. and M. J. Williams. 1993. "Machine renovation of bahiagrass pastures.” Ona Range Cattle REC Field Day Report RC 93-1. Ona: UF/IFAS Range Cattle Research and Education Center.

Katsvairo, T. W., D. L. Wright, J. J. Marois, D. Hartzog, P. K. B. Balkcom, J. Wiatrak, and J. R. Rich. 2007. "Performance of peanut and cotton in a bahiagrass cropping system." Agron. J. 99: 1245-1251.

Newman, Y. C., S. Agyin-Birikorang, M. B. Adjei, J. M. Scholberg, M. L. Silveira, J. M. B. Vendramini, J. E. Rechcigl, L. E. Sollenberger, and M. Chrysostome. 2009. "Enhancing phosphorus phytoremediation potential of two warm-season grasses with nitrogen fertilization." Agron J. 101: 1345-1351.

Newman, Y. C., J. A. Ferrell, A. R. Blount, and L. E. Sollenberger. 2008. "Seeding rate and cultivar effect on bahiagrass establishment." 21 Int. Grassl. Cong. (Hohhot, China, June 25-July 5): 209.

Sellers, B. A. and J. A. Ferrell. 2009. Weed Management in Pastures and Rangeland-2009. SS-AGR-08. Gainesville: University of Florida Institute of Food and Agricultural Sciences. http://edis.ifas.ufl.edu/wg006 
Sollenberger, L. 2019. "Finding a solution to declining bahiagrass pastures." Hay \& Forage Grower. Accessed on April 24, 2019. https://hayandforage.com/article-2364-finding-asolution-to-declining-bahiagrass-pastures.html

Sollenberger, L. E., W. R. Ocumpaugh, V. P. B. Euclides, J. E. Moore, K. H. Quesenberry, and S. C. Jones, Jr. 1988. "Animal performance on continuously stocked 'Pensacola' bahiagrass and 'Floralta' limpograss pastures." J. Prod. Agric. 1: 216-220.

Stewart, R. L., L. E. Sollenberger, J. C. B. Dubeux, J. M. B. Vendramini, S. M. Interrante, and Y. C. Newman. 2007.

"Herbage and animal responses to management intensity of continuously stocked bahiagrass pastures." Agron. J. 99(1): $107-112$.

Vendramini, J. M. B., L. E. Sollenberger, A. R. Blount, A. D. Aguiar, L. Galzerano, A. L. S. Valente, E. Alves, and L. Custodio. 2013. "Bahiagrass cultivar response to grazing frequency with limited nitrogen fertilization." Agron. J. 105(4): 938-944. 
Table 1. Total herbage production (lb DM/A) of three bahiagrass cultivars in two sites in Florida managed under grazing with different fertilization rates.

\begin{tabular}{|l|c|c|c|c|c|}
\hline \multirow{2}{*}{ Site } & \multirow{2}{*}{ N } & \multicolumn{3}{|c|}{ Cultivar } & \multirow{2}{*}{ Source } \\
\cline { 2 - 5 } & & Argentine & Pensacola & UF-Riata \\
\hline & Ib N/A yr & & lb DM/A & \\
\hline Gainesville & 180 & 10,800 & 9,300 & 8,400 & Interrante et al. 2009 \\
\hline Ona & 50 & 4,800 & 4,100 & 4,900 & Vendramini et al. 2014 \\
\hline Ona & 100 & 10,000 & 9,200 & - & Mislevy et al. 2005 \\
\hline
\end{tabular}

Table 2. Productivity of bahiagrass pastures and animal performance under different management intensity levels (nitrogen fertilization and stocking rate) in Gainesville, FL. Adapted from Stewart et al. (2007).

\begin{tabular}{|c|c|c|c|c|c|c|c|c|}
\hline \multirow[t]{2}{*}{ Management } & \multirow{2}{*}{$\begin{array}{c}\text { N Rate } \\
\text { lb/A }\end{array}$} & \multirow{2}{*}{$\begin{array}{c}\begin{array}{c}\text { Stocking } \\
\text { Rate }\end{array} \\
\text { AU/A }\end{array}$} & \multirow{2}{*}{$\begin{array}{c}\text { Herbage } \\
\text { Allowance } \\
\text { lb DM/lb LW }\end{array}$} & $\begin{array}{c}\text { Total Forage } \\
\text { Mass }^{*}\end{array}$ & $\begin{array}{c}\text { Average } \\
\text { Herbage Mass }\end{array}$ & $\begin{array}{c}\text { Herbage } \\
\text { Accumulation Rate }\end{array}$ & $\begin{array}{c}\text { Average Daily } \\
\text { Gain }\end{array}$ & \multirow{2}{*}{$\begin{array}{c}\text { Gain per } \\
\text { Area } \\
\text { lb LW/A }\end{array}$} \\
\hline & & & & \multicolumn{2}{|c|}{ lb DM/A } & $\mathrm{lb} D M / A / d$ & lb LW/d & \\
\hline Low & 36 & 0.5 & $4.8 a^{\S}$ & 3,340 & $3,040 a$ & $15 b$ & $0.75 a$ & $90 b$ \\
\hline Moderate & 107 & 1.1 & $2.0 \mathrm{~b}$ & 6,250 & $2,550 \mathrm{~b}$ & $34 a$ & $0.77 a$ & $185 a$ \\
\hline High & 320 & 1.7 & $1.4 c$ & 6,840 & $2,630 b$ & $36 a$ & $0.62 b$ & $224 a$ \\
\hline $\begin{array}{l}\text { * Calculated fro } \\
\S \text { Different lette } \\
\text { AU = Animal un } \\
\text { LW = Live weigh }\end{array}$ & $\begin{array}{l}\text { data pre } \\
\text { denote } \\
\text { equivale }\end{array}$ & $\begin{array}{l}\text { sented in St } \\
\text { tatistical dif } \\
\text { nt to a } 1,10\end{array}$ & $\begin{array}{l}\text { lart et al. }(200 \\
\text { ence }(p<0.05 \\
\text { b cow }\end{array}$ & ithin columns & & & & \\
\hline
\end{tabular}

